\title{
ISOLATION OF L-2-(1-METHYLCYCLOPROPYL)GLYCINE FROM MICROMONOSPORA MIYAKONENSIS SP. NOV.
}

\section{ISOLATION AND CHARACTERIZATION}

\author{
Jun'ichi Shoj, Ryuji Sakazaki, Toshiyuki Kato, Kazuo Tori, \\ YohKo Yoshimura and Shinzo MatsuURA \\ Shionogi Research Laboratories, Shionogi \& Co., Ltd., \\ Fukushima-ku, Osaka 553, Japan
}

(Received for publication November 17, 1980)

\begin{abstract}
A novel amino acid, L-2-(1-methylcyclopropyl)glycine was isolated from the culture broth of Micromonospora miyakonensis sp. nov. This amino acid exhibits an antimicrobial activity against Escherichia coli on a synthetic medium.
\end{abstract}

In the course of a screening program for new substances which exhibit an antimicrobial activity against Escherichia coli on a synthetic medium from the genus Micromonospora, a strain numbered PA-4046 was found to produce several active substances. Taxonomic studies presented in the preceding paper identified the strain as Micromonospora miyakonensis sp. nov ${ }^{1)}$. One of the active substances was purified and determined to be a novel amino acid, L-2-(1-methylcyclopropyl)glycine. The isolation and properties of the amino acid as well as structural studies are presented in this paper.

\section{Assay Procedure of Antimicrobial Activity}

Escherichia coli NIHJ JC-2 was used as a test organism. The organism was maintained on a slant made of Davis medium $\left(\mathrm{K}_{2} \mathrm{HPO}_{4} 0.7 \%, \mathrm{KH}_{2} \mathrm{PO}_{4} 0.3 \%\right.$, sodium citrate $0.05 \%, \mathrm{MgSO}_{4} \cdot 7 \mathrm{H}_{2} \mathrm{O} 0.01 \%$, $\left(\mathrm{NH}_{4}\right)_{2} \mathrm{SO}_{4} 0.1 \%$, glucose $0.2 \%, \mathrm{pH} 7.0$ ) and agar $2.0 \%$. To the above medium (without agar) in a test tube, the organism was inoculated and incubated at $37^{\circ} \mathrm{C}$ overnight. An assay plate was prepared using the above medium including agar $1.5 \%$ seeded with $c a .0 .02 \%(\mathrm{v} / \mathrm{v})$ of the above culture by the usual method for paper disk agar diffusion. A $6 \mathrm{~mm}$ diameter paper disk was used in these experiments for antibiotic examination.

\section{Production and Isolation}

Spores of the strain PA-4046 were inoculated into $100 \mathrm{ml}$ of a medium composed of peptone $0.5 \%$, soluble starch $0.5 \%$, glucose $0.5 \%$, beef extract $0.5 \%$, yeast extract $0.25 \%$ and $\mathrm{NaCl} 0.25 \%$, $\mathrm{pH} 7.0$, in a 500-ml Sakaguchi flask, and shake-cultured at $28^{\circ} \mathrm{C}$ for 3 days. A 4-ml portion of the culture was then transferred to $100 \mathrm{ml}$ of a medium composed of glucose $2.0 \%$, soluble starch $2.0 \%$, soy bean meal $2.0 \%$, yeast extract $0.5 \%, \mathrm{NaCl} 0.25 \%, \mathrm{CuSO}_{4} 0.0005 \%, \mathrm{MnCl}_{2} 0.0005 \%, \mathrm{ZnSO}_{4}$ $0.0005 \%, \mathrm{CaCO}_{3} 0.35 \%, \mathrm{pH} 7.0 \mathrm{in}$ a $500-\mathrm{ml}$ Sakaguchi flask, which was shake-cultured at $28^{\circ} \mathrm{C}$ for 4 days.

The culture broth obtained as above exhibited an inhibitory zone of $\mathrm{ca} .34 .0 \mathrm{~mm}$ diameter by the assay procedure described. The culture filtrate (10 liters) was passed through an ion exchange resin column of Dowex $1 \times 2\left(\mathrm{CH}_{3} \mathrm{COO}^{-}\right)(1.6$ liters $)$ at $\mathrm{pH} 10.0$. The adsorbed active substances were 
eluted with $0.3 \mathrm{~N}$ acetic acid. The eluate fractions which exhibited the activity were collected, neutralized to $\mathrm{pH} 7.0$ with sodium hydroxide and passed through a column of Diaion HP-20 (Mitsubishi Kasei Kogyo) $(120 \mathrm{ml})$. Two active substances appeared in the effluent, while two other active substances were removed by adsorption on the column. The active substances in the effluent were then adsorbed on a Dowex $50 \times 2\left(\mathrm{NH}_{4}{ }^{+}\right)$column $(500 \mathrm{ml})$ at $\mathrm{pH} 2.0$, and eluted with $0.3 \mathrm{~N} \mathrm{NH}_{4} \mathrm{OH}$. The active eluate fractions were collected, neutralized, concentrated and lyophilized, giving a residue $(4.0 \mathrm{~g})$. The residue was then subjected to preparative paper chromatography on thick filter papers (Toyo Roshi No.525) with $n$-butanol - pyridine - acetic acid-water (10:6:1:4). Two separated active substances were detected by bioautography on the assay plate or ninhydrin reaction (I: Rf ca. 0.58 and II: Rf $c a .0 .45$ ). The zone of active substance I was extracted with $50 \%$ methanol. Concentration and lyophilization of the extract gave a crude powder of substance I $(540 \mathrm{mg})$. It was further purified by preparative thin-layer chromatography on precoated silica gel plates (Merck silica gel $\mathrm{F}_{254}, 0.5 \mathrm{~mm}$ ) with $n$-butanol - acetic acid - water (4:1:2). A zone of the active substance ( $\left.\mathrm{Rf} c a .0 .27\right)$ detected by ninhydrin reaction was extracted with $50 \%$ methanol. An amorphous powder (280 mg), obtained by evaporation and lyophilization of the extract, was dissolved in $4 \mathrm{ml}$ of water, and acetone was added to the solution until the appearance of turbidity. The solution was cleared by warming and then stored at room temperature, resulting in the crystallization of the active substance I as colorless plates $(90 \mathrm{mg})$.

\section{Physico-chemical Properties and Structural Studies}

The active substance $\mathbf{I}$ obtained as colorless plates sublimes, and melts with decomposition above $210^{\circ} \mathrm{C}$ in a closed capillary. Elemental analysis indicated a molecular formula $\mathrm{C}_{6} \mathrm{H}_{11} \mathrm{NO}_{2}$. Anal. Found: $\mathrm{C}, 55.93 ; \mathrm{H}, 8.30 ; \mathrm{N}, 10.62$. Calcd. for $\mathrm{C}_{6} \mathrm{H}_{11} \mathrm{NO}_{2}: \mathrm{C}, 55.79 ; \mathrm{H}, 8.58 ; \mathrm{N}, 10.85$. The substance is soluble in water and methanol, but substantially insoluble in acetone, ethyl acetate, chloroform and ethyl ether. It gives a positive reaction to ninhydrin reagent. In the ultraviolet absorption spectrum measured in methanol, only end absorption was observed. The infrared absorption spectrum measured in $\mathrm{KBr}$ tablet is shown in Fig. 1. The substance is optically active: $[\alpha]_{\mathrm{D}}^{23.0}+120.6 \pm 5.2^{\circ}(c 0.311,5 \mathrm{~N}$ $\mathrm{HCl})$. ORD: $[\phi]_{252} 0,[\phi]_{211.5}+28300,[\phi]_{200}+17900(c 0.0847,0.5 \mathrm{~N} \mathrm{HCl})$.

The substance could not be separated from L-valine by paper chromatographic or thin-layer chromatographic experiments (Table 1), but distinguished by amino acid analysis using an automatic amino acid analyzer Hitachi KLA-5 in the usual manner. The substance appeared at the position of slightly shorter retention time than that of L-valine. When the substance was subjected to hydrolysis with

Fig. 1. Infrared absorption spectrum of L-2-(1-methylcyclopropyl)glycine (KBr).

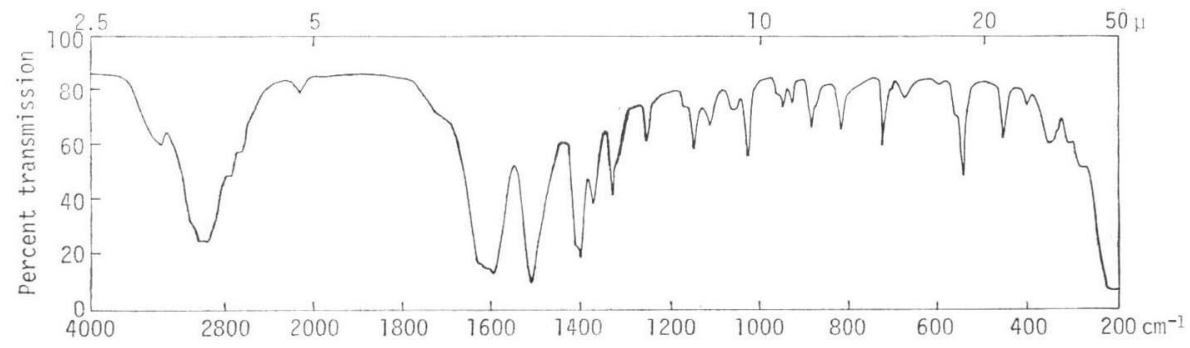


Table 1. Paper chromatography and thin-layer chromatography of L-2-(1-methylcyclopropyl)glycine.

\begin{tabular}{|c|c|}
\hline & $\mathrm{Rf}$ \\
\hline PC (Toyo Roshi No. 51) & \\
\hline$n$-Butanol-acetic acid-water $(4: 1: 2)$ & 0.51 \\
\hline $\begin{array}{l}n \text {-Butanol-pyridine - acetic acid-water } \\
\quad(10: 6: 1: 4)\end{array}$ & 0.58 \\
\hline $\begin{array}{l}n \text {-Propanol - pyridine - acetic acid - water } \\
\quad(15: 10: 3: 12)\end{array}$ & 0.63 \\
\hline $\begin{array}{l}\text { TLC (Merck Precoated Plate, Silica Gel } \\
\left.\mathrm{F}_{254} 0.25 \mathrm{~mm}\right)\end{array}$ & \\
\hline$n$-Butanol-acetic acid-water $(4: 1: 2)$ & 0.27 \\
\hline $\begin{array}{l}n \text {-Butanol-pyridine - acetic acid - water } \\
\quad(10: 6: 1: 4)\end{array}$ & 0.32 \\
\hline $\begin{array}{l}n \text {-Propanol - pyridine-acetic acid-water } \\
\quad(15: 10: 3: 12)\end{array}$ & 0.59 \\
\hline $\begin{array}{l}\text { Chloroform - ethanol - } 14 \% \text { aq. ammonia } \\
(4: 7: 2)\end{array}$ & 0.25 \\
\hline $\begin{array}{l}\text { Chloroform-ethanol-10\% acetic acid } \\
(4: 7: 2)\end{array}$ & 0.35 \\
\hline
\end{tabular}

constant boiling hydrochloric acid at $110^{\circ} \mathrm{C}$ for 20 hours, an unchanged material was recovered, showing an identical retention volume in amino
Table 2. Chemical shifts in ${ }^{1} \mathrm{H}-\mathrm{NMR}$ spectrum and ${ }^{13} \mathrm{C}-\mathrm{NMR}$ spectrum of $\mathrm{L}-2-(1-$ methylcyclopropyl)glycine.

${ }^{1} \mathrm{H}-\mathrm{NMR}$ spectrum

\begin{tabular}{ll|l}
\hline \multicolumn{2}{c|}{$\delta(\mathrm{ppm})$} & \multicolumn{1}{c}{ Proton } \\
\hline $0.4 \sim 0.9$ & $\mathrm{~m}(4 \mathrm{H})$ & $5-\mathrm{CH}_{2}$ and $6-\mathrm{CH}_{2}$ \\
1.03 & $\mathrm{~s}(3 \mathrm{H})$ & $3-\mathrm{CH}_{3}$ \\
3.09 & $\mathrm{~s}(1 \mathrm{H})$ & $2-\mathrm{CH}$ \\
\hline
\end{tabular}

${ }^{13} \mathrm{C}-\mathrm{NMR}$ spectrum

\begin{tabular}{c|c|c}
\hline$\delta(\mathrm{ppm})$ & Multiplicity & Carbon \\
\hline 174.2 & $\mathrm{~s}$ & 1 \\
63.8 & $\mathrm{~d}$ & 2 \\
18.2 & $\mathrm{q}$ & 3 \\
17.2 & $\mathrm{~s}$ & 4 \\
14.3 & $\mathrm{t}$ & 5 or 6 \\
12.3 & $\mathrm{t}$ & 5 or 6 \\
\hline
\end{tabular}

The $60-\mathrm{MHz}{ }^{1} \mathrm{H}-\mathrm{NMR}$ and $15.087-\mathrm{MHz}{ }^{13} \mathrm{C}-\mathrm{FT}$ NMR spectra were recorded on a Varian A-60A and an NV-14 spectrometer, respectively.

Both spectra were measured in $\mathrm{D}_{2} \mathrm{O}$ using DSS as an internal reference. Accuracies of $\delta_{\mathrm{H}}$ and $\delta_{\mathrm{C}}$ are within 0.02 and $0.1 \mathrm{ppm}$, respectively. acid analysis and an antimicrobial activity in the assay procedure.

The ${ }^{1} \mathrm{H}$-NMR and ${ }^{18} \mathrm{C}$-NMR spectra (Table 2), as well as the results above, suggested the structure of this substance to be 2-(1-methylcyclopropyl)glycine (I in Scheme 1). To prove the validity of the suggested structure, the substance $(13 \mathrm{mg})$ was hydrogenated in the presence of platinum oxide in an aqueous solution for 22 hours. The reaction mixture was separated by preparative thin-layer chromatography on precoated cellulose plates (Eastman Chromatogram Sheet, $20 \times 20 \mathrm{~cm}$ ) with $n$-butanol pyridine - acetic acid - water (10:6:1:4). A zone of a newly formed compound detected by ninhydrin reaction ( $\mathrm{Rf} c a .0 .58$ ) was cut out and extracted with water. It was purified by adsorption on a small column of Dowex $50 \times 8\left(\mathrm{NH}_{4}^{+}\right)$at pH 2.0 and elution with $0.3 \mathrm{~N} \mathrm{NH}_{4} \mathrm{OH}$. Lyophilization of the eluate gave a colorless powder $(4 \mathrm{mg})$. The product was proved to be 2-amino-3,3-dimethylbutyric acid (II in Scheme 1) by its ${ }^{1} \mathrm{H}-\mathrm{NMR}$ spectrum measured in a $\mathrm{D}_{2} \mathrm{O}$ - TFA solution using DSS as an internal reference: $\delta 1.36, \mathrm{~s}(9 \mathrm{H}), \delta 4.58, \mathrm{~s}(1 \mathrm{H})$.

\section{Scheme 1.}

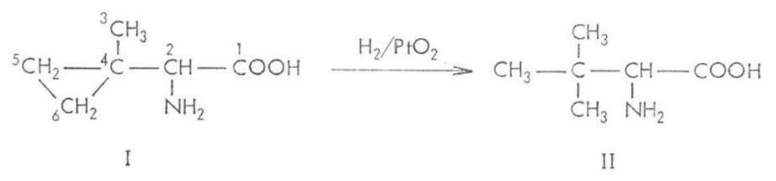

The configuration at the $\alpha$-position of this amino acid appears to be an L-form by the ORD data described in the former part. Thus, this novel amino acid is called L-2-(1-methylcyclopropyl)glycine. 


\section{Biological Properties}

Antimicrobial activity of this amino acid was assayed by paper-disk agar diffusion method. The result is presented in Table 3 . This amino acid exhibited strong antimicrobial activities against the tested strains of $E$. coli on DAvis medium. However, no activities were shown when it was assayed on nutrient medium. Subcutaneous administration of this amino acid at dose of $50 \mathrm{mg} / \mathrm{kg} \times 2$ to mice infected with $E$. coli EC-14 did not show any therapeutic effect, and intraperitoneal injection at $50 \mathrm{mg} / \mathrm{kg}$ did not show any toxic symptom.

\section{Consideration}

A novel amino acid, L-2-(1-methylcyclopropyl)glycine was isolated from Micromonospora miyakonensis sp. nov. This amino acid shows an antimicrobial activity against E. coli on a synthetic medium.

The occurrence of several amino acids containing a cyclopropane ring in higher plants has been reported: 1-aminocyclopropane-carboxylic acid in cowberry, perry pears and cider apple ${ }^{2,3)}$, hypoglycin A [3-(2-methylenecyclopropyl)alanine] in Blighia sapida ${ }^{4}$, 2-(2-methylenecyclopropyl)glycine in Litchi chinensis ${ }^{5)}$, 3-(2-methylenecyclopropyl)-3-methylalanine in Aesculus california ${ }^{6)}$, cis-2-(2-carboxycyclopropyl)glycine in Aesculus parviflora ${ }^{7)}$, trans-2-(2-carboxycyclopropyl)glycine in Blighia sapida $^{7)}$, and trans-2-(2-carboxymethylcyclopropyl)glycine in Blighia unijugata ${ }^{8)}$.

Although the isolation of two proline analogues with a bicyclic system has been reported: 3,4cyclopropylproline from Aesculus parviflora ${ }^{7)}$, and SF-1836 substance (2-azabicyclo[2,1,0]pentane-3$(S)$-carboxylic acid) from a Streptomyces strain $^{\theta)}$, this report presents the first example of the occurrence of an amino acid with a simple cyclopropane ring as a microbial metabolite.

\section{References}

1) Kawamura, Y.; Y. Yasuda \& M. Mayama: Isolation of L-2-(1-methylcyclopropyl)glycine from Micromonospora miyakonensis sp. nov. I. Taxonomic studies on the producing microorganism. J. Antibiotics 34: $367 \sim 369,1981$

2) VÄHÄtalo, M. L. \& A. I. ViRtanen: A new cyclic $\alpha$-aminocarboxylic acid in berries of cowberry. Acta Chem. Scand. 11: 741 756, 1957

3) Burroughs, L. F.: 1-Aminocyclopropane-1-carboxylic acid: A new amino acid in perry pears and cider apples. Nature 179: 360 361, 1957

4) Hassel, C. H. \& K. Reyle: Hypoglycin A and B, two biologically active polypeptides from Blighia sapida. Biochem. J. 60: 334 339, 1955

5) Gray, D. O. \& L. Fowden: $\alpha$-(Methylenecyclopropyl)-glycine from Litchi seeds. Biochem. J. 82: 385 389,1962

6) Fowden, L. \& A. SmIth: Newly characterized amino acids from Aesculus california. Phytochemistry 7: $809 \sim 819,1968$

7) Fowden, L. \& A. Sмiтн: Cyclopropane amino acid from Aesculus and Blighia. Phytochemistry 8: $437 \sim 443,1969$

8) Fowden, L.; C. M. MacGibbon, F. A. Mellon \& R. C. Sheppard: Newly characterized amino acids from Blighia unijugata. Phytochemistry 11: 1105 1110, 1972

9) Shimura, M.; M. Iwata, S. Омотo \& Y. Sekizawa: The structure of SF-1835 substance: A new antibiotic against Xanthomonas plant pathogenes. Agric. Biol. Chem. 43: 2279 2281, 1979 